\title{
Peran Religiusitas Pada Penderita HIV dan AIDS Yang Mengalami Depresi ${ }^{1}$
}

\author{
Dibyo Prasojo ${ }^{2}$ \\ Komisi Penanggulangan AIDS Prov Kalsel
}

\begin{abstract}
Being HIV-positive (people with HIV and AIDS) is a tough one in life, where complex problems are always faced daily, not just dealing with disease conditions, but disease conditions are accompanied by highly discriminatory social stigma. This stigma and discrimination often leads to depression resulting in a decrease in life spirits of people living with HIV and then bring the dominant effect of decreasing quality of life for people living with HIV. This study aims to reveal the role of religiosity in coping with depression in people with HIV and AIDS in terms of physical, psychological, social, and religiosity and factors that support the role of religiosity in coping with depression in people with HIV and AIDS. The research approach used is qualitative in the form of case studies. Subjects studied in the study are ODHA are running post-positive religiosity of HIV and AIDS consisting of 1 man and 2 women. Data collection techniques used are unstructured interviews and nonparticipant observation. While the research data collection tool used interview, observation, recorder and stationery. And the result of research data will be analyzed by using qualitative analysis technique. Based on the results of research that has been done can be stated that the role of religiosity in tackling Depression in HIV and AIDS Patients in RSUD Dr. H. Moch. Ansyari Saleh Banjarmasin is very large, seen from all subjects feel the change of attitude and view to get closer to God. Appreciate life in its true sense, enjoy life and resign to accepting circumstances. Factors that support the role of religiosity in people with HIV and AIDS in RSUD Dr. H. Moch. Ansyari Saleh Banjarmasin there are two namely: first internal factors, which are related to innate nature, and the second is external factors derived from the environment such as family and society.
\end{abstract}

Kata kunci: Peran; Religiusitas; Depresi; HIV -AIDS

\section{Pendahuluan}

HIV (Human Immunodeficiency Virus) adalah virus yang menyerang sistem kekebalan tubuh manusia yang memungkinkan berbagai penyakit masuk dan sulit untuk disembuhkan. Sedangkan AIDS (Acquired Immunodeficiency Syndrome) adalah sindrom kumpulan dari berbagai

\footnotetext{
${ }^{1}$ Tulisan ini di dasarkan pada skripsi penulis pada Jurusan Psikologi Islam Fakultas Ushuluddin dan Humaniora IAIN Antasari.

${ }^{2}$ Korespondensi untuk tulisan ini ditujukan kepada email dibyoprasojo@gmail.com
} 
gejala dan infeksi sebagai akibat dari kerusakan spesifik sistem kekebalan tubuh karena infeksi HIV pada manusia. ${ }^{3}$

Akibat dari infeksi HIV adalah kerusakan pada sistem kekebalan tubuh. HIV membunuh sel darah putih yang disebut CD4. Sel ini adalah bagian penting dari sistem kekebalan tubuh manusia, jika jumlahnya kurang maka sistem kekebalan tersebut menjadi terlalu lemah untuk melawan infeksi HIV. Jumlah sel CD4 dapat dihitung melalui tes darah khusus. Jumlah normal pada orang sehat berkisar antara 500 sel sampai 1000 sel. Setelah terinfeksi HIV maka jumlah ini akan terus menurun, jadi kadar ini mencerminkan sistem kekebalan tubuh semakin rendah dan semakin rusak. ${ }^{4}$

HIV bukan saja menyerang pada kalangan WPS L (Wanita Pekerja Seks Langsung), WPS TL (Wanita Pekerja Seks Tidak Langsung), Pengguna Narkotika Suntik, Waria, Gay, dan Pasangan Beresiko Tinggi, tetapi juga pada bayi, remaja, perempuan dan laki-laki yang taat pada agama, petugas kesehatan dan orang-orang pada umumnya. HIV menyebar sangat pesat dikalangan ribuan remaja melalui hubungan seksual. Dari data KPA Provinsi Kalimantan Selatan pada bulan Maret 2013 menyebutkan tingginya persentase yang terkena virus HIV pada rentang usia 20-29 tahun sebesar 38,9\% yang mana pada usia ini adalah masa transisi dari remaja akhir ke masa dewasa awal. ${ }^{5}$

Stigma masyarakat yang terus bermunculan selalu memojokkan ODHA (Orang dengan HIV dan AIDS), sehingga menyulitkan bagi ODHA untuk mempertahankan pekerjaan yang telah didapat sebelum terinfeksi HIV, merawat dan membesarkan anak-anaknya bagi yang sudah berkeluarga. Sikap diskriminatif juga tidak bisa luput dari kehidupan pengidap HIV, ODHA diasingkan dari kehidupan sosial, teman, pacar, bahkan dari keluarga sendiri. Tanpa disadari dengan adanya stigmatisasi dan sikap diskriminatif membuat ODHA menjadi tertutup dan tidak terbuka dengan penyakit yang diderita dan dapat menghambat proses pengidentifikasi terhadap pengidap HIV berikutnya. Sementara keadaan fisiknya secara

\footnotetext{
${ }^{3}$ Husein Muhammad, Marzuki Wahid, dan Faqihuddin Abdul Kadir, Fiqh HIV \& AIDS Pedulikah Kita? (Jakarta: Perkumpulan Keluarga Berencana Indonesia, 2010). 9

${ }^{4}$ S. Murni et al., Pasien Berdaya Seri Buku Kecil (Jakarta: Yayasan Spiritia, 2007). 5

${ }^{5}$ Komisi Penanggulangan AIDS Prov Kalsel, Laporan Triwulan Kasus HIV AIDS Triwulant I Kalimantan Selatan (Banjarmasin: Komisi Penanggulangan AIDS Prov Kalsel, 2013).
} 
progresif akan memburuk dan ini dapat mengakibatkan gangguan secara psikologis seperti rentan terhadap depresi.

Ketika seseorang dinyatakan positif HIV, maka ia akan mengalami berbagai permasalahan baik yang berkaitan dengan dirinya maupun dalam hubungan dengan lingkungannya. Keadaan ini tentu saja menyebabkan individu berada dalam kondisi yang penuh tekanan. Hal inilah yang membuat pengidap HIV enggan membuka jati dirinya karena stigma negatif tersebut. Padahal pengidap HIV juga berhak mendapat perlakuan sama dengan masyarakat pada umumnya. Rentannya penderita HIV terkena perasaan depresi ini disebabkan oleh stigma-stigma dan sikap diskriminatif dari masyarakat yang menganggap ODHA adalah manusia pendosa, hukuman atas perbuatan penderita dan penderita harus diajauhi karena dapat menyebarkan virus kepada orang yang dekat dengan dirinya dan lain sebagainya, ditambah lagi penyesalan yang mendalam atas diri penderita, marah, kecewa, bingung, putus asa tidak mempunyai harapan untuk masa depan dan masih banyak lagi yang membuat penderita menjadi rentan terhadap depresi. ${ }^{6}$

Banyak studi menyebutkan bahwa reliugisitas ([kepatuhan dalam beragama) berdampak positif bagi kesehatan (Chappati, Marie, \& Chan, 2002), termasuk di dalamnya adalah Depresi. Di Amerika, pada academy of Physicians tahun 1996, hampir semua dokter yakin bahwa keyakinan agama bisa menyembuhkan penyakit dan $75 \%$ dari mereka percaya bahwa doa-doa orang lain bisa memajukan kesembuhan (How, Ming, dan Chin, 2011). ${ }^{7}$ Menurut hasil penelitian, semakin tinggi tingkat religiusitas yang dimiliki oleh seseorang maka semakin rendah tingkat kecemasan yang dimilikinya, demikian juga sebaliknya. ${ }^{8}$

Nasution, dalam Jalaludin mengatakan religiusitas berasal dari kata religi (latin) atau relegere berarti mengumpulkan dan membaca. Kemudian religare berarti mengikat. ${ }^{9}$ Chaplin (2006) dalam Kamus Lengkap Psikologi mengartikan religi sebagai suatu sistem yang kompleks

\footnotetext{
${ }^{6}$ Imadduddin Parhani, “DINAMIKA DEPRESI PADA PENDERITA AIDS,” Jurnal Studia Insania 4, no. 2 (2016): 95-106.

${ }^{7}$ M Fais Satrianegara, "PENGARUH RELIGIUSITAS TERHADAP TINGKAT DEPRESI, KECEMASAN, STRES, DAN KUALITAS HIDUP PENDERITA PENYAKIT KRONIS DI KOTA MAKASSAR (KAJIAN SURVEI EPIDEMIOLOGI BERBASIS INTEGRASI ISLAM DAN KESEHATAN)," Jurnal Kesehatan 7, no. 1 (2014). ${ }^{8}$ Ibid.

${ }^{9}$ Jalaluddin, Psikologi Agama (Jakarta: RajaGrafindo Persada, 1998). 12
} 
dari kepercayaan, keyakinan, sikap dan upacara-upacara yang menghubungkan individu dengan suatu keberadaan atau makhluk yang bersifat ketuhanan. ${ }^{10}$ Selanjutnya, mengenai faktor spiritual, kedekatan seseorang terhadap Tuhannya dapat dilihat melalui religiusitas seseorang dalam berbagai dimensi kehidupan. Menurut Nashori dan Mucharam, religiusitas adalah seberapa jauh pengetahuan, seberapa kokoh keyakinan, seberapa palaksanaan ibadah dan akidah, dan seberapa dalam penghayatan atas agama yang dianutnya. ${ }^{11}$ Kemudian diungkap oleh Glock \& Stark, bahwa dimensi-dimensi religiusitas dalam diri seseorang, yakni dimensi keyakinan (ideological), praktik agama (ritualistic), pengalaman (experiential), pengetahuan agama (intellectual) dan konsekuensi (consequential). ${ }^{12}$

Dimensi-dimensi religiusitas mencerminkan bahwa religiusitas seseorang termanisfestasikan dalam setiap dimensi kehidupan yang dilewatinya setiap hari, termasuk ketika orang tersebut berada dalam situasi yang menakan atau berada dalam kondisi depresi. Keyakinan akan kebenaran janji Allah bahwa Allah tidak akan memberi cobaan kepada hambaNya diluar batas kemampuannya, akan memberinya rasa percaya diri akan kemampuannya menghadapi masalah. Keyakinan tersebut akan dapat dimilikinya ketika dia memiliki pengetahuan akan janji Allah terhadap hambaNya, sehingga kemudian pada praktiknya, orang tersebut tidak akan lari dari masalah ataupun berpura-pura bahwa dia sedang tidak memiliki masalah. Pengalaman-pengalaman semacam itu di sepanjang hidupnya aka memberikannya sensasi yang memberinya kemantapan hati akan keyakinannya terhadap agama dan begitu seterusnya.

Lebih lanjut, Chicoki ${ }^{13}$ mengatakan religiusitas pada penderita HIV dan AIDS adalah jalan untuk mengobati masalah emosional melalui agama dan religiusitas dengan cara:

a. Mempunyai tujuan baru: diaognosis HIV sering menjadi stimulus yang diperlukan bagi seseorang untuk menggali kembali kehidupan rohani dari kehidupan mereka.

b. Memberikan makna baru dalam hidup.

${ }^{10}$ James Patrick Chaplin dan Kartini Kartono, Kamus lengkap psikologi (Jakarta: Rajawali Pers, 1989). 482

${ }^{11}$ Fuat Nashori Nashori, Rachmy Diana Mucharam, dan Sutipyo Ru'iya, Mengembangkan kreativitas dalam perspektif psikologi islam (Yogyakarta: Menara Kudus, 2002). 71

${ }^{12}$ Rodney Stark dan Charles Y Glock, American piety: The nature of religious commitment, vol. 1 (Univ of California Press, 1968). 12

${ }^{13}$ M Cichocki, "The role of religion and spirituality in HIV: How faith and beliefs intersect with HIV," 2007. 
c. Kondisi sakit membuat penderita HIV dan AIDS menjadi pribadi yang baru.

d. Religiusitas merupakan jawaban dari pertanyaan yang muncul setelah diagnosis HIV dan AIDS. Diagnosis HIV menyebabkan rasa takut terhadap penyakit itu sendiri, takut akan adanya penderitaan, dan ketakutan akan masa depan.

Religiusitas adalah segala sesuatu mengenai kehidupan, bagian terdalam dari individu, memberikan harapan, meningkatkan keterkaitan dan hubungan dan meningkatkan kualitas hidup yang lebih. Religiusitas pada penderita HIV dan AIDS adalah poin utama pada penderita HIV dan AIDS yang merupakan jalan untuk menemukan arti dan bertahan hidup, dan menemukan tujuan untuk menghadapi tantangan dari penyakit HIV atau penyakit kronis yang ditandai oleh banyak kesalahpahaman, konflik dan perasaan bersalah.

Berdasarkan uraian dan latar belakang di atas, maka Peneliti tertarik untuk melakukan penelitian dengan tema "Peran Religiusitas dalam Menanggulangi Depresi Pada Penderita HIV dan AIDS di RSUD Dr. H. Moch. Ansyari Saleh Banjarmasin"

\section{Konsep Religiusitas}

Taylor, Lilis \& Lemone mengatakan religiusitas adalah segala sesuatu yang menyinggung tentang hubungan manusia dengan sumber kekuatan hidup atau yang Maha /memiliki kekuatan; Religiusitas adalah proses menjadi tahu, cinta dan melayani Tuhan; religiusitas adalah suatu proses melewati batas tubuh atau fisik dan pengalaman energy universal. ${ }^{14}$

Craven \& Hirnle mengatakan religiusitas adalah kualitas atau kehadiran dari proses meresapi atau memaknai, integritas dan proses yang melebihi kebutuhan bipsikososial. ${ }^{15}$ Inti religiusitas menurut Murray \& Zentner dalam Craven \& Hirnle adalah kualitas dari suatu proses menjadi lebih religious, berusaha mendapatkan inspirasi, penghormatan, perasaan kagum, memberi makna dan tujuan yang dilakukan oleh individu yang percaya maupun tidak percaya kepada Tuhan. Proses ini didasarkan pada usaha untuk harmonisasi atau penyelarasan

${ }^{14}$ C. Taylor, C. Lilis, dan P. Lemone, Fundamentals of Nursing: The art and Science of nursing care third edition (Philadelphia: Lipicott, 1997). 115

${ }^{15}$ R.F Craven dan C.J. Hirnle, Fundamentals of Nursing: Hman Health and Function Sixt Edition (Philadelphia: William \& Wilkins, 2007). 69 
dengan alam semesta, berusaha keras untuk menjawab tentang kekuatan yang terbatas, menjadi lebih focus ketika individu menghadapi stress emosional, sakit fisik atau menghadapi kematian. ${ }^{16}$

Enam kebutuhan dasar religiusitas di Amerika menurut Taylor, Lilis \& Lemone adalah sebagai berikut: ${ }^{17}$

a. Kebutuhan untuk meyakini bahwa kehidupan memberikan makna dan memiliki tujuan.

b. Kebutuhan untuk hubungan yang lebih dalam dengan komunitas. Termasuk didalamnya adalah kebutuhan untuk menguatkan atau memperkokoh hubungan dengan diri sendiri, orang lain, tuhan dan alam.

c. Kebutuhan untuk dihargai dan respek.

d. Kebutuhan untuk didengarkan dan mendengarkan.

e. Kebutuhan untuk membangun rasa saling percaya.

f. Kebutuhan untuk mempraktikkan rasa saling percaya.

Baylor University School of Nursing (BUSN) ${ }^{18}$ Kebutuhan Asuhan Religiusitas mencakup

a. Memaknai berbaagai peristiwa, tujuan hidup, dan keyakinan akan kekuatan dalam hidup.

b. Harapan hidup.

c. Keterkaitan dengan Tuhan.

d. Pengampunan atau penerimaan.

e. Transedensi

f. Terapi religiusitas

\section{Metode}

Jenis pendekatan

Jenis penelitian ini adalah penelitian lapangan yang dilakukan dengan menggunakan pendekatan kualitatif.

\footnotetext{
${ }^{16}$ Ibid. 75

${ }^{17}$ C. Taylor, C. Lilis, dan P. Lemone, Fundamentals of Nursing: The art and Science of nursing care third edition. 119

${ }^{18}$ Charles Kemp, “Klien sakit terminal: Seri asuhan keperawatan (Edisi 2)," Jakarta: EGC, 1999. 50
} 


\section{Desain Penelitian}

Metode penelitian yang digunakan adalah metode deskriptif, yaitu metode penelitian dengan cara menganalisis dan menyajikan fakta secara sistematik sehingga dapat lebih mudah untuk dipahami dan disimpulkan.

\section{Subjek dan Objek Penelitian}

Subjek dalam penelitian ini adalah 3 orang ODHA di RSUD Dr. H. Moch. Ansyari Saleh Banjarmasin dan bersedia untuk menjadi subjek penelitian yang terdiri dari 1 orang laki-laki dan 2 orang perempuan. Sedangkan informan dalam penelitian ini yaitu petugas di Klinik VCT yang juga sebagai Ketua JOTHI (Jaringan Orang Terinveksi HIV Indonesia) Kalimantan Selatan. Objek Penelitian ini adalah peran religiusitas dalam menanggulangi depresi pada penderita HIV dan AIDS di RSUD Dr. H. Moch. Ansyari Saleh Banjarmasin dan faktor-faktor yang mendukung peran religiusitas pada penderita HIV dan AIDS di RSUD Dr. H. Moch. Ansyari Saleh Banjarmasin.

\section{Data dan Sumber Data}

Data yang digali dalam penelitian ini yaitu: peran religiusitas dalam menanggulangi depresi pada penderita HIV dan AIDS di RSUD Dr. H. Moch. Ansyari Saleh Banjarmasin dan faktor-faktor mendukung peran religiusitas dalam menanggulangi depresi pada penderita HIV dan AIDS di RSUD Dr. H. Moch. Ansyari Saleh Banjarmasin. Sedangkan sumber datanya adalah ODHA dan informan

\section{Teknik pengumpulan data}

Metode yang digunakan dalam penelitian ini adalah observasi, wawancara, dan dokumentasi. Observasi dilakukan untuk mencermati atau bukti fisik berkaitan dengan gambaran peran religiusitas dalam menanggulangi depresi pada penderita HIV dan AIDS, misalnya, lingkungan, keluarga dan sebagainya. Penulis mengumpulkan data dengan cara 
mengamati secara langsung masalah-masalah yang akan diteliti melalui teknik ini akan diperoleh tentang situasi dan kondisi ODHA. Dalam teknik pengumpulan data melalui wawancara, penulis mengadakan tanya jawab secara lisan dengan para responden dan informan berkenaan dengan data yang dibutuhkan. Sedangkan dengan metode dokumentasi, penulis menggali data-data melalui dokumen atau catatan-catatan yang berhubungan dengan masalah-masalah diteliti terutama dalam hal data penunjang. Hal ini meliputi peran religiusitas dalam menanggulangi depresi pada penderita HIV dan AIDS.

\section{Analisis Data}

Setelah data diolah, selanjutnya disajikan secara deskriptif kualitatif dalam bentuk uraianuraian sehingga dapat menggambarkan permasalahan yang diteliti secara memadai dan utuh. Setelah itu dilakukan analisis data secara kulaitatif dengan merangkai dan membahas data, baik menurut teori maupun pendapat penulis sendiri. Sesudah itu ditarik kesimpulan secara induktif, yaitu pengambilan kesimpulan beranjak daari hal-hal khusus untuk selanjutnya disimpulkan secara umum.

\section{H a s i 1}

Penelitian ini dilaksanakan di RSUD Dr. H. Moch. Ansari Saleh Banjarmasin. Rumah Sakit ini meruapakan Rumah Sakit Umum Daerah Provinsi Kalimantan Selatan bertipe A yang beralamatkan di Jl. Jenderal Hasan Basri No 1 Km. 2. Banjarmasin Utara. Kalimantan Selatan. Penelitian ini dilakukan di Ruang Poliklinik XXX RSUD Dr. H. Moch Ansyari Saleh Banjarmasin. Penelitian dilakukan selama 3 bulan.

Setelah data terkumpul, kemudian dilakukan pengelompokkan data berdasarkan kategori masing-masing yaitu data tentang peran religiusitas dalam menanggulangi depresi pada penderita HIV dan AIDS serta data penunjang lainnya.

Sebelum menyajikan data satu persatu, penulis akan menyajikan identitas para subjek adalah sebagai berikut: 
Tabel. 1

Identitas Subyek Penelitian

\begin{tabular}{|c|c|c|c|c|c|c|}
\hline Nama inisial & \multicolumn{2}{|c|}{ N.H } & \multicolumn{2}{|c|}{ S.P } & \multicolumn{2}{|c|}{ N.Y } \\
\hline Usia & 29 tahun & & 45 Tahun & & 28 Tahun & \\
\hline Jenis kelamin & Perempuan & & Laki-Laki & & Perempuan & \\
\hline \multirow[t]{3}{*}{ Pekerjaan } & Ibu Rumah $\mathrm{T}$ & ngga & Wiraswasta & & Ibu Rumah & ngga \\
\hline & Pendukung & Sebaya & Pendukung & Sebaya & Pendukung & Sebaya \\
\hline & PKBI Kalsel & & PKBI Kalsel & & PKBI Kalsel & \\
\hline
\end{tabular}

\section{Peran Religiusitas Dalam Menanggulangi Depresi Pada Penderita HIV dan AIDS}

Bagian ini secara rinci menjelaskan uraian tentang tema yang terindentifikasi dari hasil wawancara dan observasi yang dilakukan secara mendalam pada subjek. Tema-tema tersebut adalah (1) mendekatkan diri pada Tuhan, (2) menghargai hidup pasca diagnosis HIV dan AIDS, (3) butuh dukungan dari orang terdekat, (4) mempunyai harapan untuk hidup lebih baik di kemudian hari.

Tema-tema dalam penelitian ini dibahas secara terpisah untuk mengungkap peran religiusitas pada penderita HIV dan AIDS, akan tetapi walaupun dibahas secara terpisah namun tema-tema ini saling berhubungan erat. Tema yang dihasilkan sangat luas dan menceritakan esensi dari pengalaman religiusitas subjek yang positif HIV dan AIDS sehingga mereka bisa memaknai peran religiusitasnya.

Berikut pengalaman peran religiusitas pada penderita HIV dan AIDS:

a. Mendekatkan diri pada Tuhan

Makna baru yang dirasakan oleh subjek dalam kehidupan religiusitas, subjek merasa lebih mendekatkan diri kepada Tuhan berupa peningkatan kegiatan keagamaan yang diawali dengan meninjau kembali kehidupan religiusitasnya setelah di diagnosa positif HIV. Sebagian besar subjek mengatakan setelah di diagnosis HIV mereka bisa belajar banyak tentang agama, memiliki kesempatan untuk bertobat dan menyadari kesalahan yang telah 
dilakukan. Karena sebagian subjek mengatakan mereka ingin lebih banyak belajar agama karena sebelumnya jauh dari Tuhan dan tidak mengamalkan ajaran agamanya secara benar.

Berikut pernyataan dari subjek N.H:

"Menyalahkan orang kada, tapi menyalahkan diri sendiri haja, karena ingat perjalanan masa lalu kebelakang yang suah gini-gini. Iya am, mungkin dengan banyak beribadah dapat mengurangi perasaan bersalah ulun. Apabila lebih mendekatkan diri dengan Tuhan maka ulun merasa pasti akan lebih sehat lagi dan bersemangat."19.

Berbeda dengan subjek lainnya yang mengatakan tidak ada perubahan dalam kegiatan keagamaannya dari sebelum terdiagnosis HIV dan pasca sudah terdiagnosis. Dengan alasan bahwa dia sudah punya pengalaman sewaktu istrinya yang sudah meninggal karena positif HIV dan AIDS juga yang dikucilkan di keluarga maupun lingkungan sekitar. Meskipun subjek merasa down ketika mengetahui dia positif HIV dan AIDS juga. Subjek juga merasa menyesal danbersalah telah ikut bergaul bersama para anak muda yang menggunakan narkoba suntik. Subjek merasa lebih ingin mendekatkan diri lagi dengan Tuhan.

Berikut pernyataan subjek S.P:

"Ketika dinyatakan postif saya langsung down juga, sebelumnya saya ga tau karena istri duluan yang dinyatakan positif dan sekarang ini istri juga sudah meninggal. Pas istri dinyatakan positif HIV, istri saya langsung di kucilkan dari keluarga maupun lingkungan sekitar rumah tempat tinggal saya. Alhamdulilah bisa, berzikir meminta kesembuhan, untuk menenangkan diri kepada Tuhan Yang Maha Esa. Ya merasa bersalah juga, kenapa jaman dulu ikut dengan para anak-anak muda menggunakan narkoba suntik pas masih kerja di tambang. Nah pas istri saya meninggal, mulai dari situ saya sudah mulai benar-benar ingin bertobat." 20

Lain lagi dengan subjek yang terakhir ini, subjek mengatakan sebelumnya sudah mendekatkan diri dengan Tuhan bukan karena menyesali karena telah terdiagnosis HIV,

${ }^{19}$ Subjek N.H Wawancara Pribadi, di Klinik VCT. 13 Februari 2014

${ }^{20}$ Subjek S.P Wawancara Pribadi, di Klinik VCT. 13 Februari 2014 
namun subjek menyadari bahwa ibadah adalah kewajiban meskipun sebelum menderita penyakit ini subjek telah melakukan ibadah sesuai keyakinannya. Subjek mengatakan sempat menyalahkan suami yang sudah meninggal duluan bekerja sebagai sopir truk di Pertambangan batu bara yang rentan dengan pergaulan bebas. Namun sekarang subjek menyadari bahwa tidak ada alasan menyalahkan siapapun karena ini memang sudah merupakan bagian hidupnya. Subjek merasa harus tetap semangat menjalani hidupnya karena subjek adalah tulang punggung keluarga setelah suaminya meninggal.

Berikut pernyataan subjek N.Y:

"karena sebelum terinfeksi itu gin ulun sudah mendekatkan diri dengan Tuhan, pas diponis oleh dokter maka ulun semakin mendekatkan diri lagi dengan yang maha kuasa, karena ulun belum tahu kalo sewaktu-waktu kena bisa dipanggil oleh yang maha kuasa dan ulun gin selalu beusaha mendekatkan diri kepada yang maha kuasa, beribadah supaya mendapatkan ampunan darinya. Waktu itu ulun kecewa lawan laki ulun, ulun sedih, menangis, sakit sudah lawas laki ulun gin sakit sudah lawas jua sampai maninggal dunia. Ujar tetangga-tetangga suami ulun behari nakal pas begawi jadi supir truk di tambang, tapi ulun kada tau. Ulun tetap semangat hidup untuk anak ulun, masa depan anak ulun, karena sadar anak ulun masih membutuhkan ulun apa lagi inya wayah ini sudah kada punya bapak lagi, ulun pang tulang punggung keluarga." 21

b. Menghargai hidup pasca diagnosis HIV dan AIDS

Tujuan hidup dan nilai-nilai religiusitas yang diyakini oleh subjek sebagian besar mengalami perubahan pasca diagnosis HIV dan AIDS. Dalam pandangan Islam orang yang sedang menderita sakit itu dapat dianggap sebagai ujian keimanan, dan untuk mengatasinya diperlukan kesabaran. Sebagian subjek mengatakan menjadi lebih menghargai hidup yang sebenarnya karena selama ini telah menyia-nyiakan hidup yang diberikan oleh Tuhan, dengan cara menjalankan semua ajaran yang diajarkan oleh agamanya dan menyadari bahwa Tuhan yang memiliki kekuatan yang Maha Besar di alam semesta ini dan kita sebagai manusia tidak punya kekuatan untuk melawan Tuhan.

${ }^{21}$ Subjek N.Y Wawancara Pribadi, di Klinik VCT. 20 Februari 2014 
“Keyakinan itu kawa mendekatkan diri kepada Yang Maha Esa, karena takdir, hidup, mati, itu semua Allah Swt yang mengatur. Kawa mengurangi perasaan bersalah jua. Supaya kita tetap bisa melanjutkan hidup kedepan jangan melakukan kesalahan yang sama, carilah pekerjaan yang positif".22

Tempat yang tepat untuk meminta pertolongan adalah kepada Tuhan pada saat subjek merasa lemah dan tidak berdaya. Karena Tuhan yang Maha Mengetahui Segala Sesuatu dan menolong hamba Nya. Selain itu subjek juga yakin bahwa Tuhan dipercaya dapat memberikan kesembuhan dari penyakit yang dialami walaupun subjek tahu bahwa mereka tidak akan sembuh dari penyakit HIV dan AIDS.

Berikut pernyataan subjek N.Y:

"karena ulun balum tau kalo sewaktu-waktu akan dipanggil oelh yang maha kuasa dan ulun pun selalu berusaha mendekatkan diri kepada yang maha kuasa, beribadah supaya mendapatkan ampunan darinya karena hanya yang maha kuasa yang mampu menolong ulun dengan kondisi ulun kaya ini". ${ }^{23}$

Nilai dan tujuan hidup yang lain dari subjek HIV dan AIDS pasca diagnosis adalah dengan pasrah dan menerima keadaan yang diberikan oleh Tuhan termasuk bila mereka harus menghadapi kematian, sebagian subjek mengungkapkan penerimaannya terhadap penyakit ini dan pasrah apabila Tuhan memang menghendaki karena ini merupakan takdir Tuhan dan semua manusia juga pasti akan kembali pada Nya.

Berikut ungkapan subjek N.H dan S.P:

"iya, mungkin dengan cara banyak beribadah dapat mengurangi perasaan bersalah dan saya lebih menyerahkan semuanya kepada tuhan, karena mungkin ini adalah kehendaknya."24

"iya, saya tidak merasa ini adalah hukuman bagi saya, saya hanya merasa ini sebagai ujian untuk mengangkat derajat saya di sisi Allah SWT."25

${ }^{22}$ Subjek N.Y Wawancara Pribadi, di Klinik VCT. 20 Februari 2014

${ }^{23}$ Subjek N.Y Wawancara Pribadi, di Klinik VCT. 20 Februari 2014

${ }^{24}$ Subjek N.H Wawancara Pribadi, di Klinik VCT. 20 Februari 2014

${ }^{25}$ Subjek S.P Wawancara Pribadi, di Klinik VCT. 13 Februari 2014 
c. Butuh dukungan dari orang terdekat

Kebutuhan religiusitas pada penderita HIV dan AIDS meliputi kebutuhan untuk menguatkan hubungan dengan diri sendiri, orang lain, Tuhan dan alam. Dukungan dan support yang tersedia di lingkungan sekitar subjek akan membantu subjek menghadapi penyakitnya. Sebagian besar subjek mengungkapkan mereka mendapatkan dukungan dari orang-orang terdekat. Dukungan yang sangat berarti diperoleh dari keluarga.

Seperti diuangkapkan oleh subjek N.H yang menjadi, mengaku dukungan dan motivasi yang didapat dari teman-teman komunitasnya sangat membantu dalam pergaulannya walaupun keluarga tidak mengetahui secara pasti apa penyakit yang dideritanya saat ini.

Berikut pernyataan dari subjek N.H, S.P, dan N.Y:

"Teman, sahabat, selalu mengingatkan tarus, memberikan dukungan seperti harus teratur menjalankan terapi obat, keluarga tau ja ulun mengonsumsi obat ARV, tapi buhan sidin kada tahu obat itu berguna gasan apa, ulun bilang ja, obat herbal". 26

“Teman dekat sampe sekarang selalu mendukung dan selalu meyakinkan saya pasti akan bisa sembuh, keluarga masih belum tahu dengan status saya yang masih dirahasiakan, belum waktunya terbuka dengan keluarga". 27

"Semua keluarga mendukung ulun, anak ulun jua taukalo mamanya sakit TB dan Paru, tapi kada tau mngidap penyakit HIV dan AIDS, kekawanan sebaya jua sangat mendukung". ${ }^{28}$

d. Mempunyai harapan untuk hidup yang lebih baik dihari depan

Harapan subjek adalah tetap bekerja seperti biasa dan membangun hubungan yang lebih baik lagi dengan orang lain dengan harapan masyarakat diluar sana nantinya akan menerima para ODHA tanpa ada stigma dan diskriminasi, sehingga para ODHA tidak merasa dikucilkan ditengah-tengah lingkungan masyarakat dan kembali menjalin

${ }^{26}$ Subjek N.H Wawancara Pribadi, di Klinik VCT. 13 Februari 2014

${ }^{27}$ Subjek S.P Wawancara Pribadi, di Klinik VCT. 20 Februari 2014

${ }^{28}$ Subjek N.Y Wawancara Pribadi, di Klinik VCT. 20 Februari 2014 
silahturahmi dengan baik. Subjek juga berharap pada pemerintah agar tetap berusaha memberikan pelayanan yang bisa memudahkan para ODHA untuk mendapatkan obatobatan secara gratis.

Berikut pernyataan dari subjek N.H, S.P dan N.Y:

"Harapan terkumpul dengan satu komunitas, supaya masyarakat bisa menerima para ODHA di masyarakat". ${ }^{29}$

"Saya dukung untuk lurus, mudah-mudahan pemerintah ini bisa selalu memberikan obatobatnya secara gratis selama-lamanya, karena takutnya sapa tau obat-obat ini dari pemerintah di putus karena obat-obat itu harganya mahal yang saat ini hanya dari apotik Kimia Farma saja yang bisa produksi, selalu memberikan semangat terhadap ODHA itu bahwa kita semua tidak putus sampe disini saja supaya semangat dan tidak merasa drop lagi"30

"HIV stop sampe disini, maksudnya pekerjaan yang tidak baik harus stop dan berhenti ke pekerjaan yang postif, tidak sembarangan lagi. Supaya kita tetap bisa berlanjut hidup kedepan jangan melakukan kesalahan yang sama, carilah pekerjaan yang positif."31

\section{Faktor-faktor yang mendukung peran religiusitas pada penderita HIV dan AIDS?}

Dari hasil wawancara dan observasi kepada seluruh objek, bahwasanya ada dua faktor yang mendukung religiusitas yaitu faktor internal dan faktor eksternal.

a. Faktor internal

Dari wawancara yang dilakukan dengan ketiga subjek, berpendapat bahwa pengalamanpengalaman mengenai keindahan-keindahan dapat membuat subjek menjadi lebih tenang, dan subjek beranggapan dengan pengalaman emosional keagaamaan maka dirinya merasa nyaman, damai, tidak merasa dijauhi lagi sehingga subjek selalu ingin mengerjakan kegiatan-kegiatan ritual sebagaimana disuruh dan dianjurkan oleh agamanya. Sebagai contoh dalam Islam, dimensi peribadatan menyangkut pelaksanaan sholat, puasa, zakat,

\footnotetext{
${ }^{29}$ Subjek N.H Wawancara Pribadi, di Klinik VCT. 20 Februari 2014

${ }^{30}$ Subjek S.P Wawancara Pribadi, di Klinik VCT. 20 Februari 2014

${ }^{31}$ Subjek N.Y Wawancara Pribadi, di Klinik VCT. 20 Februari 2014
} 
haji, membaca Al-Qur'an, doa, zikir, ibadah kurban, I'tikaf di masjid pada bulan puasa dan sebagainya.

Berikut pernyataan dari subjek N.Y:

Alhamdulilah dengan mengingat pengalaman-pengalaman mengenai keindahan yang diberikan Tuhan Yang Maha Esa ulun bisa tenang, berzikir, berdoa, dan menjalankan perintahnya, dan kada lupa jua ulun meminta kesembuhan, makanya ulun selalu mngerjakan kegiatan-kegiatan ritual itu dengan itu ulun merasa bisa menenangkan diri. ${ }^{32}$

Sedangkan faktor kebutuhan berkaitan dengan kebutuhan rasa aman dan keselamatan, kebutuhan akan cinta kasih, kebutuhan untuk memperoleh harga diri, dan kebutuhan yang timbul karena adanya kematian. Sebagian besar subjek mengungkapkan mereka mendapatkan dukungan dari orang-orang terdekatnya dalam hal ini keluarga, pasangan hidup dan teman-teman terdekat. Dukungan yang sangat berarti diperoleh dari keluarga.

Berikut ini pernyataan dari subjek N.H dan S.P:

"Teman, Sahabat, selalu mengingatkan tarus, memberikan dukungan seperti harus teratur menjalankan terapi obat, keluarga tau ja ulun mengkonsumsi obat ARV, tapi buhan sidin kada tahu obat itu berguna sigin apa, ulun bilang ja obat herbal". ${ }^{33}$

"Teman dekat sampe sekarang selalu mendukung dan selalu meyakinkan saya pasti akan bisa sembuh, keluarga masih belum tahu dengan status saya yang masih dirahasiakan, belum waktunya terbuka dengan keluarga". ${ }^{34}$

b. Faktor eksternal

Faktor eksternal yang mendukung religiusitas seseorang meliputi:

1) Lingkungan keluarga

Lingkungan keluarga dikatakan sangat berperan penting, dimana dengan lengkapnya anggota dari keluarga maka akan mendukung dalam pembentukan religiusitas seseorang. Lingkungan keluarga merupakan lingkungan pendidikan pertama dan

\footnotetext{
${ }^{32}$ Subjek N.Y Wawancara Pribadi, di Klinik VCT 20 Februari 2014

${ }^{33}$ Subjek N.H Wawancara Pribadi, di Klinik VCT. 13 Februari 2014

${ }^{34}$ Subjek S.P Wawancara Pribadi, di Klinik VCT. 20 Februari 2014
} 
utama bagi kita, karena dalam keluarga inilah kita pertama-tama mendapat pendidikan dan bimbingan. Dan dikatakan sebagai lingkungan yang utama karena sebagian besar dari kehidupan seseorang adalah didalam keluarga. sebagai contoh keluarga yang aktif dan antusias dalam kegiatan-kegiatan keagamaan seperti yasinan, mauled nabi, doa dan zikir bersama, I'tikaf dimasjid pada bulan puasa dan sebagainya, disekitar lingkungan keluarga dan masyarakat, maka secara tidak langsung akan terbentuklah karakter lingkungan keluarga yang religi, sopan santun, berempati.

Berikut ini pernyataan dari subjek N.Y:

"Lingkungan keluarga ulun dipadahi agamis kada jua pang, biasa-biasa ja, karna ulun menjalankan jua ajaran-ajaran agama yang suah di ajarkan oleh orang tua ulun dulu dan sekarang ulun merasakan lingkungan keluarga itu sangat banyak bepengaruh dalam perkembangan religiuisitas ulun, dimana ulun kada gampang menyerah dalam menjalani hidup ini sehabis ulun dipadahkan positif HIV". 35

2) Lingkungan masyarakat

Lingkungan masyarakat adalah tempat terjadinya sebuah interaksi suatu sistem dalam menghasilkan sebuah kebudayaan yang terkait oleh norma-norma dan adat istiadat yang berlangsung dalam kurun waktu yang lama dimana seseorang dapat memberikan pengaruh pada lingkungannya tapi sebaliknya, juga dapat menerima pengaruh dari lingkungan masyarakat tersebut.

Berikut ini pernyataan dari Subjek S.P dan N.H:

"Lingkungan masyarakat menurut saya sangat mendukung reliugisitas seseorang karena menurut saya lingkungan sangat berpengaruh besar dengan perilaku, apabila kita tidak bisa mengendalikan diri maka kita bisa terjerumus dalam pergaulan-pergaulan yang negatif seperti saya ini, tetapi tidak semuanya negatif koo, buktinya sekarang saya sudah dapat berubah menjadi lebih positif, meninggalkan kehidupan lama saya dengan bergaul dengan teman-teman sebaya (komunitas)" 36

${ }^{35}$ Subjek N.Y Wawancara Pribadi, di Klinik VCT. 13 Februari 2014

${ }^{36}$ Subjek S.P Wawancara Pribadi, di Klinik VCT. 20 Februari 2014 
"sangat mendukung karena lingkungan tempat tinggal sangat berpengaruh lawan perkembangan reliugisitas orang, apabila tinggal di wadah yang baik, maka insyaallah baik jua dapatnya dan bila kada baik yaa kada baik aee". ${ }^{37}$

\section{Diskusi}

Peran religiusitas dalam menanggulangi Depresi pada penderita HIV dan AIDS

Penelitian ini menemukan 4 tema untuk mengungkapkan pengalaman makna religiusitas pada subjek positif HIV dan AIDS. Gambaran tentang perubahan religiusitas dan tujuan hidup yang terjadi dalam kehidupan subjek pasca dinyatakan positif HIV dan AIDS pada tema pertama yaitu mendekatkan diri pada Tuhan. Tentang tujuan hidup pasca diagnosis HIV dan AIDS dan gambaran nilai dan kepercayaan yang diyakini subjek pasca diagnosis HIV dan AIDS teridentifikasi pada tema kedua yaitu menghargai hidup pasca diagnosis HIV dan AIDS. Tema ketiga yaitu butuh dukungan dari orang terdekat, dan tema keempat yaitu mempunyai harapan untuk kehidupan yang lebih baik dihari depan.

a. Mendekatkan diri pada Tuhan

Hasil penelitian ini menemukan makna baru yang dirasakan oleh subjek setelah didiagnosis positif HIV dan AIDS yaitu merasa lebih dekat kepada Tuhan. Sejalan dengan apa yang dikatakan oleh Taylor Lilis \& Lemone bahwa agama bisa merupakan dari religiusitas dan memiliki dua komponen yaitu orientasi terhadap keagamaan dan orientasi terhadap eksistensi. ${ }^{38}$ Pada penelitian ini didapatkan hasil lebih mendekatkan diri kepada Tuhan diawali dengan menyadari kesalahan yang telah diperbuat, kemudian direalisasikan dengan keinginan untuk bertaubat kepada Tuhan. Begitu juga yang dirasakan ketiga subjek N.H, S.P dan N.Y menggunakan penyakit mereka sebagai cara untuk lebih memahami religiusitas mereka dan diri mereka sendiri.

Speck, dalam Kemp menyebutkan makan juga mencakup makna menjelang ajal, keberadaan manusia, penderitaan dan usia hidup yang tersisa ditandai dengan rasa

\footnotetext{
${ }^{37}$ Subjek S.P Wawancara Pribadi, di Klinik VCT. 20 Februari 2014
}

${ }^{38}$ C. Taylor, C. Lilis, dan P. Lemone, Fundamentals of Nursing: The art and Science of nursing care third edition. 119 
bersalah, menghadapi situasi hidup yang menyakitkan. ${ }^{39}$ Para subjek pada penelitian ini mengalami rasa bersalah yang berat akibat perasaan menyimpang atas dosa atau tanggung jawab mereka sendiri terkait dengan keadaan yang menyakitkan dikehidupan mereka dan kesalahan mereka dimasa lalu karena menggunakan narkoba, melakukan seks bebas dan ada juga yang tertular oleh suami.

Pada penelitian ini ditemukan juga subjek tetap melakukan kegiatan keagamaan dengan melakukan sholat semampunya, zikir dan berdoa memohon ampunan. Sejalan dengan hasil penelitian Natalya tentang mekanisme dan strategi koping orang dengan HIV dan AIDS (ODHA) dalam menghadapi stress karena penyakitnya di Yogyakarta mengatakan salah satu strategi koping yang digunakan oleh klien dengan HIV dan AIDS adalah dengan berhubungan dengan kekuatan supernatural yaitu dengan berdoa, memohon ampunan dan melakukan sholat. ${ }^{40}$

b. Menghargai hidup pasca diagnosis HIV dan AIDS

Nilai religiusitas yang diyakini subjek antara lain lebih menghargai makna hidup yang sebenarnya, menikmati hidup dan pasrah menerima keadaan. Menghargai makna hidup diinterprestasikan dengan melaksanakan semua ajaran agama masing-masing. Sebagian besar subjek meyakini bahwa Tuhan memiliki kekuatan yang Maha Besar di alam semesta ini untuk mengatur segala sesuatu. Subjek mengungkapkan bahwa Tuhan adalah Sang Pencipta, Maha Memberi Rezeki, Maha Melihat, Mengetahui dan Maha Mendengar dan tempat mengadu apabila mereka merasa tidak berdaya. Tujuan hidup yang diungkapkan subjek adalah ingin menikmati hidup, yang diungkapkan dengan keinginan dan kehidupan yang lebih baik, bisa merasakan hidup teratur karena sebelumnya ada subjek N.H dan S.P yang merasa telah menyia-nyiakan kehidupannya dengan pergaulan bebas. Pasca diagnosis HIV subjek baru menyadarinya dan merasakan bahwa sebenarnya hidup ini indah. Subjek lain mengatakan hanya ingin hidup normal seperti orang lain dan memanfaatkan kesempatan yang diberikan oleh Tuhan.

\footnotetext{
${ }^{39}$ Kemp, "Klien sakit terminal: Seri asuhan keperawatan (Edisi 2)." 40

${ }^{40}$ Wiwiek Natalya, "Mekanisme dan strategi koping orang dengan HIV/AIDS (ODHA) dalam menghadapi stres akibat penyakitnya di Yogyakarta," 2006. 45
} 
Chicoki mengatakan bahwa dengan religiusitas akan menghilangkan perasaan takut dan penderitaan yang dialami partisipan serta memberikan perasaan tenang secara emosional, hal ini menjawab kekhawatiran subjek karena diagnosis HIV menyebabkan perasaan takut karena stigma yang melekat pada penyakit HIV.41

Tujuan hidup selanjutnya adalah pasrah dan menerima keadaan. Beberapa subjek mengungkapkan bahwa menganggap penyakit HIV ini sebagia berkah, ujian dari Tuhan dan pada dasarnya mereka sudah ikhlas hanya belum merasa yakin, sehingga mereka berharap tetap diberi kekuatan hati untuk menjalaninya. Termasuk didalamnya adalah kesiapan subjek untuk menghadapi kematian, sebagian besar mengungkapkan ketakutannya akan kematian, dan pengalaman subjek yang lain karena merasakan stigma dan diskriminasi di lingkungan masyarakat.

c. Butuh dukungan dari orang terdekat

Dukungan terhadap subjek N.H, S.P dan N.Y pasca terdiagnosis HIV sebagian besar adalah oleh keluarga dalam hal ini pasangan hidup dan orang tua. Teman-teman dekat yang berasal dari komunitas yang sama juga turut memberikan dukungan. Hal ini didukung oleh hasil penelitian Emblen \& Halstead (1993); Highfield \& Cason (1983); O’Brien (1999) bahwasanya termasuk didalamnya adalah kebutuhan untuk menguatkan atau memperkokoh hubungan dengan diri sendiri dan orang lain, Tuhan dan alam. Komponen model meliputi social terdiri dari keintiman hubungan dengan orang lain, keluarga, teman dan rekan kerja. ${ }^{42}$

Semua subjek mengungkapkan mereka mendapatkan banyak dukungan dari orang-orang terdekatnya dalam hal ini keluarga dan teman-teman. Dukungan yang sangat berarti diperoleh keluarga dalam hal ini pasangan hidup dan orang tua. Teman-teman dekat yang berasal dari komunitas yang sama juga turut memberikan dukungan. Penelitian Vitriawan tentang pengalaman partisipan pertama kali terdiagnosis HIV dan AIDS mengatakan berbagai mekanisme koping dan adaptasi klien pertama kali terdiagnosis HIV dan AIDS adalah terbuka dengan orang lain, menyemangati diri sendiri, dan pada akhirnya mencoba

${ }^{41}$ Cichocki, "The role of religion and spirituality in HIV: How faith and beliefs intersect with HIV."

${ }^{42}$ M.L Wright, Sprituality, Suffering \& IIIness: IDeas for Healing (Philadelphia: F.A Davis Company, 2005). 55 
menyesuaikan diri dengan lingkungan; setiap klien pertama kali terdiagnosis HIV dan AIDS membutuhkan dukungan dari lingkungan sekitarnya. ${ }^{43}$

Hal senada didapatkan Natalya dalam penelitiannya mengatakan bahwa ODHA membutuhkan dukungan sosial. Penelitian telah menunjukan bahwa orang yang mendapatkan dukungan sosial tinggi dan hubungan intim memiliki sistem kekebalan tubuh lebih kuat dan lebih sedikit terkena penyakit. ${ }^{44}$

d. Mempunyai harapan untuk kehidupan yang lebih baik dimasa depan

Harapan subjek adalah tetap bekerja seperti biasa dan membangun hubungan yang lebih baik lagi dengan orang lain dengan harapan masyarakat di luar sana nantinya akan menerima para ODHA tanpa ada stigma dan diskriminasi, sehingga para ODHA tidak merasa dikucilkan ditengah-tengah masyarakat dan kembali menjalin silaturahmi dengan baik tanpa ada tanpa ada stigma dan diskriminasi lagi. Subjek juga berharap pada pemerintah agar tetap berusaha memberikan pelayan yang bisa memudahkan para ODHA untuk mendapatkan obat-obatan secara gratis. Seperti pernyataan dari ketiga subjek bahwasanya komunitas seperjuangan menghadapi HIV dan AIDS dapat membantu membangkitkan semangat hidup para ODHA yang juga diiringi dengan I'tikad baik dari pemerintah dalam memberikan fasilitas obat-abatan.

Hal ini sejalan dengan Kemp yang mengatakan tidak adanya makna dalam kehidupan manusia diungkapkan dengan berbagai cara melalui kehilangan harapan dan keputusasaan. ${ }^{45}$ Hal senada disampaikan oleh Conrad yang mengatakan bahwa harapan adalah faktor penting dalam menghadapi stress, dalam mempertahankan kualitas hidup dan untuk melanjutkan hidup. ${ }^{46}$

\footnotetext{
${ }^{43}$ Welly Vitriawan, Ratna Sitorus, dan Yati Afiyanti, "Pengalaman Pasien Pertama Kali Terdiagnosis HIV/AIDS: Studi Fenomenologi Dalam Perspektif Keperawatan," Jurnal Keperawatan Indonesia 11, no. 1 (2007): 6-12.

${ }^{44}$ Natalya, "Mekanisme dan strategi koping orang dengan HIV/AIDS (ODHA) dalam menghadapi stres akibat penyakitnya di Yogyakarta." 45

${ }^{45}$ Kemp, "Klien sakit terminal: Seri asuhan keperawatan (Edisi 2)." 52

${ }^{46}$ Ibid. 53
} 
Komponen harapan menurut Post-White adalah menemukan makna dalam religiusitas, memiliki hubungan yang menguatkan, mengandalkan sumber dalam diri, menjalani hidup setiap hari dan mengantisipasi kelangsungan hidup di masa depan. ${ }^{47}$

Tuck \& Thinganjana mengatakn religiusitas adalah sumber inspirasi berupa harapan. Iman dan kekuatan untuk memelihara hidup atau menerima pemberian, selain itu merupakan proses pencarian akan makna hidup yang diwujudkan dengan harapan-harapan yang baik untuk kehidupan barunya pasca diagnosis HIV dan AIDS. Hasil penelitian menunjukkan bahwa religiusitas digunakan sebagai cara untuk mengatasi penyakit HIV dan AIDS yang digunakan sebagai koping positif. ${ }^{48}$

Harapan adalah pengenalan secara konstruktif terhadap kemungkinan-kemungkinan pada satu situasi kehidupan dan kepercayaan pada nilai kehidupan pada saat ini dan masa depan. Berhenti dan bertahan pada satu situasi, kehilangan pegangan hidup dan tenggelam pada satu situasi tertekan akan eksistensi diri, focus pada ketidakmampuan dan kehilangan harapan akan masa depan merupakan faktor yang berkontribusi terhadap keputusasaan yaitu situasi hidup dalam kehampaan, tidak ada hari esok, mental yang jatuh dan tidak ada harapan atau alasan lagi untuk hidup. Pada saat subjek bangkit dan memiliki harapan maka harapan akan meningkat kembali. Proses diatas merupakan proses yang dinamis. Semua objek dalam penelitian ini memiliki harapan yang positif akan kehidupan yang baik di masa depan.

2. Faktor-faktor yang mendukung peran religiusitas pada penderita HIV dan AIDS ?

a. Faktor Internal

Thoules menjelaskan bahwa faktor internal yang dapat mendukung sikap religiusitas seseorang yaitu faktor pengalaman dan kebutuhan. Faktor pengalaman berkaitan dengan pengalaman-pengalaman mengenai keindahan, konflik moral, dan pengalaman emosional keagamaan. Sedangkan faktor kebutuhan berkaitan dengan kebutuhan rasa

${ }^{47}$ Ibid. 56

${ }^{48}$ I. Tuck, N.L Mc. Cain, dan R.K. Elswick Jr, "Spirituality and Psychosocial factors in Person living with HIV," n.d., www. ncbi.nlm.nih.gov. 
aman dan keselamatan, kebutuhan akan cinta kasih, kebutuhan akan harga diri dan kebutuhan yang timbul karena adanya kematian. ${ }^{49}$

Seperti yang dirasakan ketiga subjek N.H, S.P dan N.Y bahwa pengalaman-pengalaman mengenai keindahan-keindahan dapat membuat subjek menjadi lebih tenang, dan subjek beranggapan dengan pengalaman emosional keagamaan maka dirinya merasa nyaman, damai, tidak merasa dijauhi lagi sehingga subjek selalu ingin mengerjakan kegiatan-kegiatan ritual sebagaimana disuruh dan dianjurkan oleh agamanya.

b. Faktor eksternal

1) Lingkungan Keluarga

Lingkungan keluarga dikatakan sebagai lingkungan yang utama karena sebagian besar dari kehidupan seseorang ada didalam keluarga. Seperti halnya yang terjadi pada subjek N.Y, dimana subjek merasa lingkungan keluarga sangat memegang peranan penting dan sangat berpengaruh dalam pengembangan religiusitas subjek, dimana subjek tidak merasa mudah menyerah dalam menjalani hidup ini sehabis dinyatakan positif. Glock \& Stark (Nashori, F, Mucharam, R. D. 2002) menyatakan bahwa fase sosialisasi awal bagi pembentukan konsep religiusitas seseorang adalah keluarga. ${ }^{50}$ Selain itu Sigmund Freud menyebutkan melalui konsep gambar ayah menjelaskan bagaimana citra seorang ayah akan mempengaruhi perkembangan religiusitas anaknya. Sehingga dapat dikataka bahwa keluarga sangat memegang peranan penting dalam menentukan bagaimana religiusitas seseorang. ${ }^{51}$

2) Lingkungan Masyarakat

Lingkungan masyarakat dapat berperan membentuk karakter. Misalnya, lingkungan tempat tinggal di asrama militer, maka anak-anak yang tinggal disana cenderung lebih berani karena mereka merasakan adanya label dari orang tua mereka. Mereka juga bersikap lebih semena-mena kepada teman-temannya yang lain. lingkungan yang seperti ini akan membentuk karakter anak menjdai keras, pribadi yang galak, apa yang dia inginkan harus segera terlaksana. Lingkungan

\footnotetext{
${ }^{49}$ Robert H. Thouless, Pengantar Psikologi Agama (Jakarta: Rajawali Press, 2000). 46

${ }^{50}$ Nashori, Mucharam, dan Ru'iya, Mengembangkan kreativitas dalam perspektif psikologi islam. 85

${ }^{51}$ Ibid. 87
} 
masyarakat juga dpat berpengaruh baik. Misalnya dengan memilih tinggal di sebuah perkampungan dipinggiran kota. Yang di lingkungan tersebut terdapat masjid dan remajanya pun aktif dan antusias dalam kegiatan-kegiatan agama untuk masyarakat sekitar baik orang tua, remaja bahkan anak-anak kecil. Suasana lingkungan menjadi hidup, dinamis, agamis, harmonis serta menyenangkan hati masyarakat yang tinggal dilingkungan tersebut. Maka terbentuk karakter yang sopan santun, beradaptasi, berempati, serta dapat menjadi manusia yang berjiwa social. Seperti yang dirasakan oleh subjek S.P lingkungan masyarakat sangat mendukung religiusistas seseorang, karena menurut subjek lingkungan sangat berpegaruh besar terhadap perkembangan perilaku, apabila kita tidak bisa mengendalikan diri maka kita bisa terjerumus dalam pergaulan-pergaulan yang negatif.

Masyarakat merupakan lingkungan interaksi sosial dan sosiokultural yang potensisal mendukung religiusitas seseorang. Seseorang akan cenderung menampilkan perilakunya sesuai dengan lingkungan pergaulannya. Thoules berpendapat bahwa tradisi-tradisi sosial yang berlandaskan nilai-nilai keagamaan dan tekanan lingkungan untuk menyesuaikan diri sengan berbagai sikap yang disepakati oleh lingkungan dapat mendukung religiusitas seseorang. Berdasarkan hal diatas, dapat disimpulkan bahwa kualitas religiusitas seseorang dapat dilihat dari bagaimana orang-orang disekitarnya. ${ }^{52}$

\section{Kesimpulan}

Peran religiusitas dalam menanggulangi Depresi Pada Penderita HIV dan AIDS di RSUD Dr. H. Moch. Ansyari Saleh Banjarmasin sangatlah besar, terlihat dari semua subjek merasakan perubahan sikap dan pandangan untuk mendekatkan diri kepada Tuhan. Menghargai kehidupan dalam arti yang sebenarnya, menikmati hidup dan pasrah menerima keadaan.

\footnotetext{
${ }^{52}$ Robert H. Thouless, Pengantar Psikologi Agama. 47
} 
Faktor-faktor yang mendukung peran religiusitas pada penderita HIV dan AIDS di RSUD Dr. H. Moch. Ansyari Saleh Banjarmasin ada dua yaitu: pertama faktor internal, yang berkaitan dengan pembawaan dari dalam diri, dan yang kedua adalah faktor eksternal yang berasal dari lingkungannya seperti keluarga dan masyarakat.

\section{Saran}

Bagi OHIDA dan masyarakat umum hasil penelitian ini diharapkan dapat menjadi pertimbangan dalam menghadapi penderita HIV. OHIDA dan masyarakat sebaiknya memberikan dukungan sosial yang besar terhadap para ODHA dan memperlakukan para ODHA seperti manusia pada biasanya, tanpa ada stigma dan diskriminasi yang dapat memunculkan rasa depresi. Sedangkan untuk penelitian selanjutnya, diharapkan agar dapat memperhatikan faktor-faktor eksternal maupun internal lain yang memungkinkan terjadinya depresi.

\section{Kepustakaan}

C. Taylor, C. Lilis, dan P. Lemone. Fundamentals of Nursing: The art and Science of nursing care third edition. Philadelphia: Lipicott, 1997.

Chaplin, James Patrick, dan Kartini Kartono. Kamus lengkap psikologi. Jakarta: Rajawali Pers, 1989.

Cichocki, M. "The role of religion and spirituality in HIV: How faith and beliefs intersect with HIV," 2007.

Husein Muhammad, Marzuki Wahid, dan Faqihuddin Abdul Kadir. Figh HIV $\mathcal{E}$ AIDS Pedulikah Kita? Jakarta: Perkumpulan Keluarga Berencana Indonesia, 2010.

I. Tuck, N.L Mc. Cain, dan R.K. Elswick Jr. "Spirituality and Psychosocial factors in Person living with HIV," n.d. www. ncbi.nlm.nih.gov.

Jalaluddin. Psikologi Agama. Jakarta: RajaGrafindo Persada, 1998.

Kemp, Charles. “Klien sakit terminal: Seri asuhan keperawatan (Edisi 2)." Jakarta: EGC, 1999.

Komisi Penanggulangan AIDS Prov Kalsel. Laporan Triwulan Kasus HIV AIDS Triwulant I Kalimantan Selatan. Banjarmasin: Komisi Penanggulangan AIDS Prov Kalsel, 2013. 
M.L Wright. Sprituality, Suffering \& Illness: IDeas for Healing. Philadelphia: F.A Davis Company, 2005.

Murni, S., C. W. Green, S. Okta, dan H. Setyowati. Pasien Berdaya Seri Buku Kecil. Jakarta: Yayasan Spiritia, 2007.

Nashori, Fuat Nashori, Rachmy Diana Mucharam, dan Sutipyo Ru'iya. Mengembangkan kreativitas dalam perspektif psikologi islam. Yogyakarta: Menara Kudus, 2002.

Natalya, Wiwiek. “Mekanisme dan strategi koping orang dengan HIV/AIDS (ODHA) dalam menghadapi stres akibat penyakitnya di Yogyakarta," 2006.

Parhani, Imadduddin. “DINAMIKA DEPRESI PADA PENDERITA AIDS.” Jurnal Studia Insania 4, no. 2 (2016): 95-106.

R.F Craven, dan C.J. Hirnle. Fundamentals of Nursing: Hman Health and Function Sixt Edition. Philadelphia: William \& Wilkins, 2007.

Robert H. Thouless. Pengantar Psikologi Agama. Jakarta: Rajawali Press, 2000.

Satrianegara, M Fais. "PENGARUH RELIGIUSITAS TERHADAP TINGKAT DEPRESI, KECEMASAN, STRES, DAN KUALITAS HIDUP PENDERITA PENYAKIT KRONIS DI KOTA MAKASSAR (KAJIAN SURVEI EPIDEMIOLOGI BERBASIS INTEGRASI ISLAM DAN KESEHATAN)." Jurnal Kesehatan 7, no. 1 (2014).

Stark, Rodney, dan Charles Y Glock. American piety: The nature of religious commitment. Vol. 1. Univ of California Press, 1968.

Vitriawan, Welly, Ratna Sitorus, dan Yati Afiyanti. "Pengalaman Pasien Pertama Kali Terdiagnosis HIV/AIDS: Studi Fenomenologi Dalam Perspektif Keperawatan." Jurnal Keperawatan Indonesia 11, no. 1 (2007): 6-12. 